\title{
The Impact of Interest Rate, Inflation Rate, Time to Maturity and Bond Rating: Indonesia Case
}

\author{
Dwi Kusriyanto, Nelmida
}

Indonesia Banking School, Jalan Kemang Raya No.35, RT.7/RW.1, Bangka,

Corresponding author: Mampang Prapatan, Jakarta 12730, Indonesia

\section{ABSTRACT}

This study aims to analyze the impact of interest rate, inflation rate, time of maturity, and bond rating on yield to maturity corporate bonds listed on the Indonesia Stock Exchange. The type of data in this study is secondary data. The object of research is all corporate bonds of banking companies listed on the Indonesia Stock Exchange in 2015 - 201\%. The sampling technique used is purposive sampling with a total of 70 bonds. This study used multiple regression analysis. Based on the results, shows that the Bank Indonesia interest rate, the maturity period has a positive effect on yield to maturity, while the bond rating does not affect yield to maturity. However, the inflation rate does not affect the yield to maturity. This result can be used by academics, investors and Regulators.

Keywords:

interest rate, inflation rate, time of maturity, bond rating, yield to maturity 


\section{INTRODUCTION}

A capital market is a place where people can buy and sell financial securities, for instance, shares and bonds. Furthermore, the capital market also contributes to the economic and financial developments in a country. According to its functions, the capital market plays a role as an intermediary for those who have surplus funds (investors) and those who require funds (issuers). For investors, the capital market provides varied investment alternatives that generate opportunities for greater profits. For issuers, the capital market can provide other funding sources to conduct operational activities including business expansion in addition to banking credit. There are two types of investments that must be known, namely real assets and financial assets. Investment in financial assets is the type of investment that is most often carried out by investors because it is generally intangible but still has a high value. One of the financial assets traded on a stock exchange is a bond. The bonds themselves are divided into two types, government bonds, and corporate bonds. Bonds are one type of securities that traded through OTC (Over the Counter) or cannot be done through exchange, however every transaction needs to be reported to the Indonesia Stock Exchange (IDX) through the Central Trading Platform (CTP) reporting system, with the aim that prices information can be more transparent to the investors in the market. Bonds are longterm debt that will be repaid at maturity with a fixed interest. The bond value is written on the debt letter (Hartono, 2009). Issued bonds by the government of the Republic of Indonesia namely as government bonds, while other issued bonds by companies, whether by StateOwned Enterprises (BUMN) even private business entities, are corporate bonds. (Manurung et al, 2008). The Indonesia Stock Exchange (2010), defines bonds as transferable medium-to-long-term debt securities that contain agreement from the issuing party to pay compensation in the form of interest in a precise period and repay the principal at a predetermined time to the buyer of the bond. Faerber, Esme (1993), stated that bonds are the same as bank savings. When investors place their money, after that the bank will give interest to investors. This also can be applied to bonds trading mechanism, investors who buy bonds, lend money to the bond issuer and get interested in the loan. When the loan is due (on the bond's maturity date), the investor will receive the principal value (principal) of what has been invested. This term is the same as the owner of the savings will get the money that they save in the bank when they make a withdrawal. The biggest difference between savings and bonds is that investors can sell the bonds to

\footnotetext{
${ }^{1}$ Thomas Nagel (2012), Mind and Cosmos: Why the Materialist Neo-Darwinian Conception of Nature is Almost Certainly False, Copyright Oxford University Press, Print ISBN-13: 9780199919758, Pp. 23.

2 Phillip Johnson, (1998), Afterword: How to Sink a Battleship, Mere Creation: Science, Faith and Intelligent Design, ed. William Dembski (Downers Grove, Ill.:InterVarsity, 1998), Pp.448-449.

${ }^{3}$ Vaffi Foday Sheriif (2016), Faith As The Foundation of Human Progress: Nursi's Perspective, Quest Journals Journal of Research in Humanities and Social Science Volume 4 Issue 8 (2016) Pp: 73-80 ISSN(Online) : 2321-9467

${ }^{4}$ Usama Hasan and Athar Osama (2016), Muslim Responses to Science's Big Questions, Muslim World Science Initiative, Report of İhsanoğlu Task Force on Islam and Science. Pp. 217-220.

${ }^{5}$ Muhammad Amin Samad, (2017), CIVIC, 21April 2017, Academia, https://www.academia.edu/32715858/4. BEDIUZZAMAN_SAID_NURSI_1876-1960_.pdf.

${ }^{6}$ Vaffi Foday Sheriif (2016), II : 799

${ }^{7}$ M. Fethullah Gülen (2004), Toward a global civilization of love and tolerance, Çaðlayan A.S. Izmir, Turkey, ISBN 1-932099-68-9, Pp 291.
} 
other investors before the maturity of the bonds, while savings cannot be sold to other investors. Therefore, bonds are negotiable debts, unlike savings. Fabozzi, Frank. J. (2000: 1) stated that bonds are debt instruments that require the issuer (the debtor) to pay a sum of money borrowed plus interest to the investor (the creditor) at the specified time. Bodie, Zvi, Kane, Alex, and Marcus, Alan. J, (2007) stated that bonds are securities that require the issuer to make certain payments to bondholders for a certain period. Keown, Arthur. J., (2004) stated that bonds are a type of debt or long-term payment promissory note issued by the borrower, who promises to pay the holder a certain amount of interest each year. Bonds as the investment instrument offer yield (profit level) for investors. Bond yield is the most significant factor for investors to consider buying bonds as their investment instrument. Tandelilin (2001), stated that bond yield is a measurement of bond income that investors will receive, which tends to be non-permanent. Bond yields are not fixed, as is the interest on bonds, because the bond yield will be strongly related to the level of return the investor suggests. While Samsul (2006), stated that yield is an advantage on bond investment which is expressed in percentages. Fabozzi, Frank. J. (2000) stated that several bond yield indicators can be used by investors, namely current yield and yield to maturity (YTM). According to Brigham and Houston (2010), stated that yield to maturity is the level of profit that investors will receive if they buy bonds at current market prices and hold the bonds to maturity. An investor who buys a bond and owns it until the bond is due will receive the yield to maturity at the date of purchase, but the yield to maturity bond calculated will often change between the date of purchase and the maturity date. According to Tandelilin (2001), stated that yield to maturity is widely used as bond yield measurement because the yield reflects the return by the compound rate of return expected by investors. As an investment instrument, changes in yield to bond maturity obtained by investors experience changes over time. The aim of investing is to get benefits in the form of bond coupon payments and capital gains. Capital gain is obtained when selling the bonds held by investors (Nasher and Surya, 2011). In real practice, investors are not fully aware of the various factors that can affect bond yields. Whereas, by knowing the factors that can affect bond yields, investors can maximize the yield. As the yield at maturity, it can also be the promised rate of return. This is a return that an investor will receive if all the agreed payments are made. However, yield to maturity will be the same as the expected rate of return if the probability of default is zero. Therefore, investors and issuers must always pay attention to factors that affect changes in yields from bonds. These factors include market interest rates (reference rates from the central bank), inflation, growth in the gross domestic product (GDP), changes in

\footnotetext{
${ }^{8}$ Qazi Mohd. Jamshed (2016), Badiuzzaman Said Nursi's approach to modern education - integrating science with religious sciences, Proceedings of ADVED 2016 2nd International Conference on Advances in Education and Social Sciences 10-12 October 2016- Istanbul, Turkey

${ }^{9}$ Ingmar Karlsson (2008), Turkish Islam and European values - two irreconcilable concepts? Beyond Nordic Legal Modernity, Reykjavik.

${ }^{10}$ Eric J Chaisson, (2013), Cosmic Evolution, Harvard publications.

${ }^{11}$ Faruk Arslan (2014), A hear -based Sufi mindfulness spiritual practice employing self-journeying, Theses and Dissertations (Comprehensive). Wilfrid Laurier University, Pp 213.

${ }^{12}$ Ingmar Karlsson (2008), Turkish Islam and European values - two irreconcilable concepts? Beyond Nordic Legal Modernity, Reykjavik.
} 
exchange rates (foreign exchange rates), bond maturity, bond ratings, bond coupons, corporate profitability, total assets of the company, debt to equity ratio. However, based on the experience of researchers as dealers in the bond market, market participants directly focus on a number of factors including the Bank Indonesia benchmark interest rate, inflation rate, bond maturity and bond ratings, because these four factors are considered very influential on the yield rate for an investment in the bond market. Kristina's research (2010), concluded that the variable SBI interest rates did not affect yield to maturity. This is because the overall interest rate has a fairly high average, causing transactions in bonds to decline. In contrast, research conducted by Nurfauziah and A.F. Setyarini (2004) stated that the SBI interest rate does not affect the yield to maturity. Research conducted by Nurfauziah and Adistien Fatma Setyarini (2004) showed that there is a positive relationship between inflation rate and bond yields. An inflation rate that continues to increase causes an overall increasing price, thus, securities investment such as bonds will be felt riskier. As a result, investors will expect higher yields on their investments. This is in line with the research of Tbrahim (2008) and Surya and Nasher (2011) which stated that inflation has a positive and significant effect on bond yields. But the opposite was obtained from Lidya (2010) and Sam'ani (2008) which stated that the results of the research on inflation variables had a negative and insignificant effect on bond yields. Research conducted by Amihud and Mendelson (1991) stated that maturity has a positive effect on yield to maturity, which means that the longer the maturity period, the greater the yield to maturity of bonds. Meanwhile, the results of different studies presented by Nurfauziah and Setyarini (2004) stated that maturity does not affect the yield to maturity. The research results by Khurana and Raman (2003), Ibrahim (2008) and Surya and Nasher (2011) stated that bond rating negatively affects the yield to bond maturity, which means that the higher the bond rating, the lower the yield to bond maturity. Meanwhile, Nurfauziah and Setyarini (2004) and Zuhrohtun and Zaki Baridwan (2006) stated that bond ratings did not affect yield to maturity. Based on the explanation above and the results of previous studies, this study aims to examine the impact of Bank Indonesia's benchmark interest rate, inflation rate, bond maturity and bond ratings towards yields to maturity in listed corporate bonds at the Indonesia Stock Exchange.

\section{IITERATURE RFVIFW Concept of Theory}

Bond

Bonds are transferable medium-long-term debts that contain agreement from the issuing party to pay compensation in the form of interest in a certain period and repay the principal at a predetermined time to the buyer of the bond. According to Warsono (1997, in Andry, 2005), bond emissions can be viewed from two sides, namely from the issuer and from the investor side. One of the main objectives of the issuer's company to issue bonds is to increase the company's value, because the cost is relatively more affordable compared to the issuance of new shares, with greater financial risk consequences. In terms of investors, bond issuance is a safe alternative investment, because bonds provide fixed income in the form of interest coupons that are paid regularly with a competitive interest rate and principal payable that paid on time at the predetermined maturity date. 
Bond Yield

Rahardjo (2003), stated that bond yield is the most significant factor for investors to consider buying bonds as their investment instrument. Bond investors will calculate the amount of investment income on the funds using the yield measurement tool. According to Fabozzi (2000) in Setyapurnama and Norpratiwi (2006), stated that there are two terms in determining yield, namely current yield and yield to maturity. Factors that influence the value of bond yields include Bank Indonesia's benchmark interest rate, inflation rate, bond maturity, and bond rating.

\section{Interest Rate (BI Rate)}

Interest rate is a policy interest rate that reflects the monetary policy stance set by Bank Indonesia and announced to the public. Robert Ang (1997), said that the amount of bond yield is influenced by market interest rates. The relationship between the interest rate of the bond and the deposit rate is in the opposite direction (negative). If the market interest rate increases then it is also followed by an increase in deposit interest, as a result, the bond interest rate decreases so that the bond yield will increase. In contrast, if the market interest rate falls, the deposit interest falls as a result of the bond interest rate rising so that the bond yield value will decrease.

\section{Inflation Rate}

The rate of inflation is an increase in the price of basic goods continuously over a while (Samuelson and Nordhaus, 2001). As a result of inflation is an increase in the company's production costs and will have an impact on the decline in company performance. For market participants, this kind of situation is less preferred as for conservative investors who prefer fixed income, it is necessary to consider the risks associated with the inflation rate. As is known that the risk of inflation will cause a decrease in the real value of money or income. In the context of bond investment, if the inflation rate has increased, there will be a decrease in the real value of interest income earned by investors during the life of the bond. Besides, the inflation rate is also related to the interest rate, if the inflation rate increases then interest rates will tend to increase, which will have an impact on the bond market interest rate and consequently will affect the value of bond yields. If investors estimate an increase in inflation, investors will ask for greater compensation due to a decrease in the real value of cash flows obtained from bonds. Therefore, in conditions where inflation is estimated to rise, bond prices will decrease but the yield will increase (Tandelilin, 2001).

\section{Bond Maturity}

The due date is the maturity period of the bond, now the issuer will pay off all loans by the agreed terms. The maturity of a bond is at the same time used to show the age of the bond. Bonds that have a longer maturity will have a higher level of risk, and vice versa. Therefore, investors prefer to buy bonds that have a shorter maturity. Tandelilin (2001) explains that if there is a decrease (increase) in the interest rate, then the bond price will go up (down), but a relatively larger percentage of price changes will occur in bonds that have a longer maturity and lower coupon rates. Therefore, bonds with a certain maturity period can be used as the investor's choice to avoid losses.

\section{Bond Rating}

Bond ratings are one of the important indicators in the decision-making process 
to buy bonds, particularly corporate bonds. Debt rating is an assessment of the issuer's creditworthiness. The definition of creditworthiness used is based on how likely the company will fail to pay and the protection that the creditor has if there is a default (Ross et. Al, 2008). The rating given by the rating agency will state whether the bond is at the level of investment grade or non-investment grade. A bond that receives a non-investment grade rating is referred to as a junk bond. Whereas a bond that previously included investment grade but after review and its rating dropped to noninvestment grade, such bonds are usually called falling angels (Ang, 1997).

\section{Previous Study and Hypothesis}

The influence of Bank Indonesia's interest rate on yield to maturity. According to the previous research, Hadiasman Ibrahim (2008), examined the factors that influence the yield level of corporate bonds on 22 listed corporate bonds on the Stock Exchange during 2004. The results of this study indicated that SBI interest rates have a positive and significant effect on yield to maturity (YTM). Furthermore, Lidya Kristina (2010) conducted a study on the effect of interest rates, on yield to maturity of bonds at listed companies at the Indonesia Stock Exchange in the period 2006-2008, which concluded that SBI interest rates had a negative influence on yield to maturity. This is because the overall interest rate has a fairly high average, which causes the transaction to decline. Hanung Huboyojati and Endang Tri Widyarti (2011) conducted a study to analyze the effect of SBI interest rates on corporate bond yield spreads with the 2008-2009 study period. The results of the study show that the SBI interest rate has a positive and significant effect on the corporate bond yield spread. Wiryandari and Artini (2012) conducted a study of 44 bonds during the period 2010 - 2011. The results showed that SBI interest rates had a positive and significant effect on bond yields. Furthermore, Nanik Indarsih (2013) examined 30 bonds from 19 companies in the period 2007 - 2010 and the results obtained that SBI interest rates have a positive and significant relationship to yield to maturity. Desnitasari (2014) examined the effect of interest rates on yield to maturity of corporate bonds listed on the Stock Exchange in the period 20102012, concluding that the interest rate has a significant effect on the yield to maturity of corporate bonds. Based on the results of previous studies, the following hypothesis can be formulated:

$\mathrm{Hl}$ : Interest rate has effect on yield to maturity

\section{The Effect of Inflation Rate on Yield to Maturity}

The research results on the effect of inflation rates on bond yield values have been carried out with some distinctive results. Ida Ayu Made Wiryandari Kusuma Handayani and Luh Gede Sri Artin (2013), examined the effect of inflation on Yield to Maturity of Corporate Bonds in the Indonesia Stock Exchange 2010 - 2011. The research result indicated that the inflation rate has a positive and significant effect on Yield to Maturity. In contrast, according to the research results that conducted by Riama Yanti Ginting (2014), Ni Wayan Linda Naluritha Sari Nyoman Abundanti (2015), Anhar Firdaus Gultom (2016), showed that inflation rate is against Yield to Maturity of Corporate Bonds. Based on the results of previous studies, the following hypothesis can be formulated:

H2: The inflation rate affects yield to maturity. 
The Effect of Date Maturity on Yield to Maturity

Nanik Indarsih (2013) has researched 30 bonds from 19 companies between the period of 2007 and 2010 . The results obtained that bond maturity has a positive and significant relationship to yield to maturity. Desnitasari (2014), examined the effect of interest rates, bond ratings, company size and debt to equity ratio on yield to maturity of corporate bonds listed on the Stock Exchange between the period of ¿010 and 2012. concluded simultaneously, interest rates, bond ratings, company size and debt to equity ratio has a significant influence on yield to maturity of listed corporate bonds on the IDX for the period 2010-2012 with a contribution of $33.1 \%$, while $66.9 \%$ remaining is the influence of excluded variables. Based on the theory and results of previous studies, it can be formulated:

H3: The date to maturity effects on yield to maturity.

\section{The Effect of Bond Rating on Yield to} Maturity

Hadiasman Ibrahim (2008), concerned the factors that influence the yield level of corporate bonds on 22 bonds from several listed companies on the Stock Exchange during 2004. The research results indicated that bond ratings have a negative and significant effect on yield to maturity. Rinaningsih (2009), researched the effect of the bond rating on bond yield and lead to the results of negative and significant. Desnitasari (2014), who examined the effect of bond ratings on yield to maturity of listed corporate bonds on the Stock Exchange in the period 2010-2012, concluded that the bond rating had a significant influence on the yield to maturity of listed corporate bonds on the IDX. Based on the previous research results, the following hypothesis can be formulated:

H4: The bond rating affects on yield to maturity.

\section{METHODS}

\section{Research Design}

This research is explanatory research, which is a research that explains the position of the variables studied and the relationship between one variable and another variable (Umar, 2005). Thus, this research aims to analyze the relationship between interest rate, inflation rate, maturity date, and bond rating on corporate bond yield to maturity. The object of this research is a banking company that issues bonds and is listed on the Indonesia Stock Exchange in 2015 - 201\%.

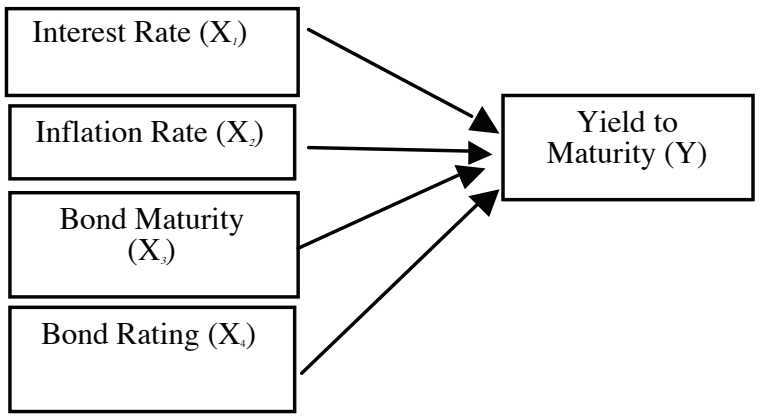

Figure 1. The Effect of Independent Variables on Dependent Variables 


\section{Population and Sample}

The sampling technique used in this research is purposive sampling method, defined as the method of selecting samples based on certain criteria. The criteria used in the sampling are as follows: (i) Bonds that issued in rupiah denomination, (ii) Bonds that issued by listed banking companies (conventional banks) on the IDX, excludes Subordinated Bonds (subdebt), (iii) Banking corporate bonds that have an investment grade (> BBB) rating issued by the securities rating agency PT. Pefindo, (iv) Banking corporate bonds that have data in the form of prices, coupons, nominal, and maturity dates of bonds, ( $v$ ) Banking corporate bonds do not have special features (callable and puttable) so they do not create a bias towards the yield obtained, (vi ) Corporate banking bonds with fixedrate and non-floating rate coupons.

Based on the sample criteria above, 70 bonds were obtained as samples with the number of issuers as many as 15 banking companies.

\section{Types and Data Sources}

The type of data used in this study is secondary data. According to Sekaran (2004), states that secondary data is the data that has been published by individuals, groups or agencies to certain parties which are quantitative. The data needed in this research is in the form of Bank Indonesia reference interest rate, inflation rate, bond maturity, and bond rating. While the data sources are obtained through the Indonesia Stock Exchange website, PT. Indonesian Securities Rating Agency (Pefindo), Financial Services Authority (OJK) and Bloomberg System.

\section{Operational Variables}

In general, the variables used in this research model consist of the dependent variable and the independent variable. The dependent variable is yield to maturity, while the independent variables consist of the SBI interest rate, inflation rate, bond maturity, and bond rating.

\section{Dependent variable}

Yield to maturity (YTM) is the gain on bond investment which is expressed as a percentage (Samsul, 2006), or can be interpreted as the level of compound return that investors will receive if they buy bonds at current market prices and hold the bonds to maturity (Hadiasman Ibrahim, 2008). The YTM formula is as follows a formula (1):

$\mathrm{YTM}=\frac{C+\frac{F-P}{n}}{\frac{F+P}{2}} \times 100$

\section{Explanation:}

YTM : Yield to Maturity

C : Coupon

N : remaining date to maturity

F : Face Value (nominal value)

$\mathrm{P} \quad$ : Bond Price at $\mathrm{t}=0$

\section{Independent variables}

1. Interest Rate.Interest rate is the value of an interest rate following the amount issued by the Central Bank (Bank Indonesia).

2. Inflation rate

The inflation rate is the tendency of rising prices of goods and services, in general, to take place continuously, where the inflation rate is issued by the Central Statistics Agency (BPS) and Bank Indonesia.

3. The maturity date

Due date (maturity date) is the date when the principal value of the bond must be repaid by the bond issuer (Krisnilasari, 2007). 


\section{Bond-rating}

Bond-rating is a symbolic statement about the state of the issuing company issued by PT. Pefindo. The bond rating variable is given a rating symbol and is determined by classifying the rank according to its ranking category. Furthermore, bond ratings are categorized into two categories from PT. Pefindo includes:

a. Investment-grade consists of idAAA, idAA +, idAA, idAA-, idA +, idA, idA-, idBBB +, idBBB, idBBB-.

b. Non-investment grade consists of $i d B B+, i d B B, i d B B-, i d B+, i d B, i d B-$, idCCC, idD.

\section{Analysis Method}

The analytical method used to test the hypothesis about the strength of the independent variable on the yield to maturity of bonds, in this study used multiple regression analysis with the leastsquares equation. Before a multiple linear regression analysis is performed, all data must be free from classical assumptions or data must be BLUE (Best least-square underestimate) by testing normality, multicollinearity, heteroscedasticity, and autocorrelation. The regression equation model used is as follows formula 2 :

$Y T M=a+\beta_{1} I+\beta_{2} I N F+\beta_{3}$ Maturity

$+\beta_{4}$ Rank $+e$
Explanation:

YTIM = yield to maturity

I = interest rate

Maturity = time to maturity

Rank = bond rating

\section{The Goodness of Fit Model Test.}

The Goodness of Fit Model test is conducted to see the feasibility of the model used, namely by using the statistical $F$ test and the Determination Coefficient (R Square). For the statistical $F$ test, the result of $F$ is calculated by comparing to the $\mathrm{F}$ table with alpha 5\%. If the $\mathrm{F}$ calculated value is greater than the F table value, it can be concluded that the model has fulfilled the Goodness of Fit or the used model is feasible, vice versa. Hypothesis testing is conducted by using a statistical t-test (partial test). Statistical t-test aims to determine whether each independent variable individually affects the dependent variable by comparing $t$ table values and $t$ count values with a $5 \%$ error rate or with a $95 \%$ confidence level. If the calculated value of $t$ is greater than the $t$ table value or a significant value is lower than the alpha error rate of $5 \%$, then it can be sum up that the independent variable has a significant effect on the dependent variable, and vice versa.

\section{RESULTS AND DISCUSSIONS}

\section{Results of Descriptive Analysis}

Analysis of descriptive statistics of this study can be seen in Table 1 .

Table 1. Results of Descriptive Analysis

\begin{tabular}{lrrrrr}
\hline \multicolumn{1}{c}{ Variable } & N & Min & Max & Mean & Dev. Std. \\
\hline YTM & 70 & 2.5127 & 3.2069 & 2.9229 & 0.1683 \\
\hline Interest rate & 70 & 2.1794 & 2.8723 & 2.3865 & 0.2198 \\
\hline INF & 70 & 1.8138 & 2.7857 & 2.1210 & 0.2501 \\
\hline M & 70 & 1.2247 & 3.2404 & 2.2342 & 0.5186 \\
\hline Rank & 70 & 2.1213 & 3.2404 & 3.0970 & 0.2586 \\
\hline Valid N (listwise) & 70 & & & &
\end{tabular}


Based on the results of the descriptive analysis in Table 1 can be explained as follows:

a. Yield to Maturity; The lowest yield to maturity value is 2.5127 and the highest is 3.2069. While the average value is 2.922, and the standard deviation value shows several 0.1683. This shows that the data distribution for the standard deviation of yield to maturity is good and the variable data is normally distributed because the average value is greater than the standard deviation value.

b. Interest rate; The lowest Bank Indonesia benchmark interest rate was 2.1794 and the highest was 2.8723. The average values and standard deviations are 2.3865 and 0.2198 respectively. The standard deviation value showed that there is no significant gap in the Bank Indonesia benchmark interest rate from 2015-2017.

c. Inflation Rate; The lowest inflation rate was 1.8138 and the highest was $2.785 \%$. For the average value and standard deviation are 2.1210 and 0.2501. The standard deviation value showed that there is no significant gap in the inflation rate from 2015-201\%.

d. Bond Maturity; The lowest value of bond maturity in this study is 1.2247 and the highest is 3.2404. The average value of maturity is 2.2342 and the standard deviation value is 0.5186 , which means that the maturity time does not have a large gap during the period of research.

e. Bond Rating; The lowest bond rating value is 2.1213 and the highest is 3.2404. The average value is 3.0970 and the standard deviation value is 0.2586 .

\section{Quantitative Analysis Results}

The quantitative analysis method used in the study is a multiple linear regression method. Before doing multiple linear regression analysis all data must be free from classical assumptions. All used data has passed the classical assumption test such as normality test, multicollinearity test, heteroscedasticity test, and autocorrelation test. From the results of the classic assumption test, all data have met the requirements to be continued by doing multiple linear regression analysis. Based on multiple linear regression analysis, the results are shown in Table 2.

Based on the results of multiple linear regression as shown in table 2 , the regression equation can be made as shown in equation (3).

$\mathrm{YTM}=2,049+0,517 \mathrm{I}-0,068 \mathrm{INF}+$

0,166Maturity - 0,189Rank

From equation (3) it can be interpreted that if the BI rate, inflation rate, bond maturity and bond rating are constant, the yield to maturity value is $2.049 \%$. If the BI rate increases by $1 \%$ with the assumption of inflation rate, maturity time and bond rating are constant, then the yield to maturity value will increase by $0.517 \%$. However, if the inflation rate rises by $1 \%$ assuming BI rate, maturity and bond rating are constant, the yield to maturity value will decrease by $0.068 \%$. Furthermore, if the maturity period increases by $1 \%$ assuming $\mathrm{BI}$ rate, inflation rate, and bond rating are constant, then the yield to maturity value will increase by $0.166 \%$. Besides, if the bond rating has increased by $1 \%$ assuming $B I$ rate, inflation rate, and bond maturity are constant, then the yield to maturity value will decrease by $0.189 \%$.

According to the results of multiple linear regression analysis as shown in Table 2 , it can be indicated that the results of the statistical $F$ test ( $F$ count) are 82.670 
Table 2. Multiple Regression Testing Results

\begin{tabular}{ccccc}
\hline & Beta & $\begin{array}{c}\text { Coefficients } \\
\text { Std. Error }\end{array}$ & $t$ & Sig. \\
\hline (Constant) & 2.049 & 0.148 & 13.865 & 0.000 \\
\hline BI rate & 0.517 & 0.051 & 10.180 & 0.000 \\
\hline INF & -0.068 & 0.045 & -1.522 & 0.133 \\
\hline M & 0.166 & 0.016 & 10.050 & 0.000 \\
\hline Rank & -0.189 & 0.033 & -5.733 & 0.000 \\
\hline F-Statistic & & & 82.679 & 0.000 \\
\hline Adj R Square & 0.826 & & & \\
\hline
\end{tabular}

greater than the $\mathrm{F}$ table value with alpha $5 \%$ (2.51), this shows that the used model has met Goodness of fit requirements or the used model is appropriate. Besides, the Adjusted R Square value of 0.826 (82.6\%), which means that the independent variable of $\mathrm{BI}$ rate, inflation rate, bond maturity, and bond rating contributes yield to maturity of $82.6 \%$, and $2 \% .4 \%$ remaining is influenced by other factors that excluded in this study model. Therefore, it can be said that the used model is Goodness of Fit or the used model is feasible, thus, that further analysis can be carried out, namely testing the hypothesis.

Furthermore, based on the hypothesis test, it also can be seen in Table 2 that BI rate has a positive and significant effect on yield to maturity value because the significant value of $\mathrm{BI}$ rate is zero lower than the $5 \%$ alpha error rate, said BI's benchmark interest rate has a positive effect on the yield to maturity value means that if the interest rate increases, the yield to maturity value will also increase, and vice versa. This research is following the theory put forward by Tandelilin (2001), which stated that a high-interest rate will cause the increasing return indicated by the investor. The results of this study are consistent with the results of research by Hadiasman Ibrahim (2008), Hanung Huboyojati and Endang Tri
Widyarti (2011), Surya and Nasher (2011), Wiryandari and Artini (2012), Purnawati (2013), and Nanik Indarsih (2013), in contrast, the research results of Nurfauziah and Setyarini (2004) and Lidya Kristina (2010) found that the SBI interest rate did not affect the yield to bond maturity.

Table 2 also shows that the inflation rate does not affect the yield to maturity value because the significant value of the inflation rate is 0.133 greater than the 5\% alpha error rate. The results of this study are in contrast to the theory of Bodie, Kane, and Marcus (2007), but in line with the results of Nurfauziah and Setyarini (2004), Sam'ani (2008) and Lidya (2010) found that the inflation rate has no effect on the yield to maturity value. Furthermore, from Table 2 also indicates that the significant value of maturity is zero, which is less than the alpha error rate of $5 \%$, it can be said that the maturity time has a positive effect on the yield to maturity value, to sum up, that if the maturity is longer, thus, the yield to Bond maturity will be higher, and vice versa. The results of this study are in line with Jones's (2000) theory. Also, it is supported by the results of research by Khurana and Raman (2003) and Purnawati (2013) who found that maturity time has a positive effect on the yield to maturity value. In conclusion, based on the research results 
in Table 2, it is also seen that the significant value of the bond rating influence on the yield to maturity value is zero, less than the alpha error rate of $5 \%$, which means that the bond rating negatively affects the yield to maturity value. In other words, the higher bond ratings the lower yield to maturity values, and vice versa. The results of this study are consistent with the theory of Bodie, Kane, and Marcus (2007) and in line with the research results by Hadiasman (2008), Rinaningsih (2009), Surya and Nasher (2011) who found that bond ratings negatively affect the yield to maturity value. In contrast, the research results from Nurfauziah and Setyarini (2004) and Nanik Indarsih (2013), indicated that bond ratings do not affect the yield to maturity value.

\section{CONCLUSION}

According to the research results and discussion, the following conclusions can be made: (1) BI's benchmark interest rate has a positive effect on yield to maturity value, (2) inflation rate has no effect on yield to maturity value, (3) due date has a positive effect on yield value to maturity, and (4) bond ratings has a negative effect on the yield to maturity value. Based on the conclusion, several suggestions can be made:
(1) for investors who want to invest in bonds, they will consider BI's benchmark interest rate, maturity time and bond rating since these factors affect the yield to maturity of the banking corporation bonds listed on the IDX specifically in the investment-worthy category. (2) For the government as a suggestion to conduct policies to control interest rate by Bank Indonesia and the inflation rate. (3) For the academics, as a reference for future research. This study has other limitations: (1) The scope of research is limited to banking companies that issue bonds, while still companies that also issue bonds are expected for future research to expand the scope of the research so that the number of samples is more biased, and the results of the research will be more general nature. (2) There are only four independent variables used, interest rate, inflation rate, maturity and bond ratings, while there are other factors that can influence yield to maturity, for instance, liquidity and profitability. Therefore, for future researchers to add more research variables. (3) The analysis method used in this study is the multiple linear regression analysis, while there are still other analytical methods that can be used, for instance, ARMA, ARIMA, etc. 


\section{RFFERFNCES}

Alexander, G.J and Bailey, J.V (1995). Investment. Prentice-Hall, New York.

Bodie, Zvi, Kane, Alex and Marcus, Alan.J. (2007). Investments. McGraw Hill Higher Education; rth edition.

Desnitasari, Isnaini (2014). Influence of Interest Rate, Bond Rating, Company Size and Yield to Maturity of Corporate Bonds in the Indonesia Stock Exchange Period 2010-2012. Journal. Telecommunications and Informatics Business Management Study Program. Telkom University.

Fabozzi, Frank J. (2000) Bond Market analysis and strategies, International edition, fourth edition, Prentice Hall International, Inc.

Ghozali, Imam. (2006). Aplikasi Analisis Multivariate dengan Program SPSS (4th Edition). Semarang: Issuing Board of Diponegoro University.

Haming, Murdifin dan Basalamah, Salim. (2010). Studi Kelayakan Investasi Proyek dan Bisnis. Jakarta: Bumi Aksara

Huboyojati, Hanung and Widyarti, Endang Tri (2010). Analisis Pengaruh Tingkat Suku Bunga SBI, Likuiditas Obligasi, Rating Obligasi, dan Return On Equity Perusahaan terhadap Yield Spread Obligasi Perusahaan. Jurnal Studi Manajemen \& Organisasi, Vol.7, No.1, 2010.

Indarsih, N. (2013). Pengaruh Tingkat Suku Bunga SBI, Rating, Likuiditas dan Maturitas terhadap Yield to Maturity Obligasi. Jurnal Ilmu Manajemen.

Jones, P, Charles, (2004). Investments Analysis and Management. Eighth Edition, John Willey \& Son, Inc.

Keown, Arthur J., Martin, John D., Petty, J William, \& Scott, David F. (2004). Principles and Implementation of Financial Management. Pearson Education Inc, New Jersey.

Khurana, Inder K., and K.K. Raman. (2003). Are Fundamental of The Bond Market? Contemporary Accounting Research, Vol. 3.

Manurung, A.H., Silitonga, D., Tobing, W.R.L. (2008). Hubungan Rasio-rasio Keuangan dengan Rating Obligasi. Working Paper.

Nasher \& Surya. (2011). Analisis Pengaruh Tingkat Suku Bunga SBI, Exchange Rate, Ukuran Perusahaan, Debt to Equity Ratio, dan Bond terhadap Yield Obligasi Korporasi di Indonesia. Jurnal Manajemen Teknologi. Institut Teknologi Bandung. Vol. 10. No. Z.

Nurfauziah dan Adistien F. Setyarini (2004). Analisis Faktor-Faktor yang Mempengaruhi Yield Obligasi Perusahaan (Studi Kasus Pada Industri Perbankan dan Industri Finansial), Jurnal Siasat Bisnis, Vol. 2 No. 9.

Purnamawati, I Gusti (2013). Pengaruh Peringkat Obligasi, Tingkat Suku Bunga Sertifikat Bank Indonesia, Rasio Laverage, Ukuran Perusahaan dan Umur Obligasi Pada Imbal Hasil Obligasi Korporasi di Bursa Efek Indonesia. VOKASI Jurnal Riset Akuntansi, vol. O2. No. 01.

Rahardjo, Sapto. (2003). Panduan Investasi Obligasi. PT. Gramedia Pustaka Utama.

Rinaningsih. (2009). The Influence of Corporate Practise Towards Credit and Bond Yields. Journal of Indonesian Economy and Business. Vol. 24, Number 2, 2009. 249-265.

Ross, Westerfield, Jordan. (2008) Introduction to Corporate Finance (8th Ed). Jakarta, Publisher Salemba Empat.

Samsul. (2006). Pasar Modal dan Manajemen Portofolio. Jakarta. Erlangga.

Samuelson, Paul A and William D Nordhaus (2001). Macro-Economics. Fourteenth Edition. Jakarta: Erlangga.

Setyapurnama, Y., \&e Norpratiwi, A. V. (2006). Pengaruh Corporate Governance terhadap Peringkat Obligasi dan Yield Obligasi. Jurnal Akuntansi dan Bisnis, r. 
Tandelilin, Eduardus. (2010). Portfolio and Investment. Theory and Application. First Edition. First Print. Kanisius, Yogyakarta.

Wiryandari Kusuma Handayani dan Sri Artini. 2012. Pengaruh Faktor Ekonomi Makro, Keputusan Investasi dan Keputusan Pendanaan Terhadap Yield Obligasi Korporasi di Bursa Efek Indonesia. Jurnal Manajemen Fakultas Ekonomi Universitas Udayana. pp:249264..

Zuhrotun dan Zaki Baridwan. (2006). The Effect of Rating Announcement on Bond Performance. Jurnal Sosiosains 19 (1), pp.45-58.

Zubir, Z. 2012. Bond Portfolio. First edition. Salemba Empat. Jakarta 